\title{
Hiphopkulturen i København - et møde med en anden måde at leve på
}

Af Lis Engel

Hiphopkulturen er en måde at leve og udtrykke sig på. Alle udtryksformerne, både billeder, musik, poesi og dans er meget kropslige. D. J.'en danser sin musik frem ved at bruge to grammofoner som om det var et trommesæt. Graffitimalerne udfører en form for 'action'film for at kunne udføre deres kæmpemalerier på vanskeligt tilgængelige og ofte forbudte steder. Rapperne siger deres rytmiske poesi, så det rykker i hele kroppen, både på dem selv og publikum. Alle hiphopkulturens udtryksformer udspringer af en kropslighed, der involverer alle sanser. Oplevelser og livserfaringer udtrykker på én gang glæder og positivt anderledes værdier og frustrationer og oprør med stivnede vaner og normer. Det er en kultur, hvor det med hiphoppernes egne ord handler om »at udtrykke sig selv agte «og »at benytte sig af humor og høj energi som midler til at fortælle om værdier, som handler om »at protestere mod stive normer og former «,»om at have det sjovt«,»om at kunne improvisere $i$ фjeblikket«,»om at kunne flyde $i$ nuet«eller som det også udtrykkes med et ironisk smil af de danske hiphoppere: »Piece, Unity, Love and Having Fun«. Kulturens selvforståelse er antivold, antiracisme og at vende det negative til noget positivt. "Det er klart, at temaerne i Danmark må være helt anderledes end i USA, « siger Lasse fra Hvid Sjokolade, en af grupperne fra den nye $\mathrm{CD}$ med dansk undergrundsrap, De grimme ællinger: »Vi prædiker ikke, vi benytter os mere af humor og ironi. Vi fortæller om helt almindelige hverdagsting, sådan som vi oplever det. Det ville føles falsk, at lave tekster om mord og vold.«

Hiphopkulturen virker umiddelbart, som om det er en rendyrket drengekultur med en masse karakteristika, der taler til klassiske maskuline dyder, som styrke, behændighed, høj energi. Det kan aflæses af kropslige attituder, kraft- og konkurrencebetonede bevægelser som de ses i 'break dance', de rituelle dansekonkurrencer, de indbyrdes konkurrencer med at blive synlig og hævde sig som f.eks graffittimalernes ildhu for at anbringe deres 'tags' (deres navnetegn) på særligt imponerende (forbudte eller vanskelige) steder. Selv om pigerne umiddelbart ikke er så fremtrædende i miljøet, er der piger, der har en høj status i miljøet. Pigerne er derimod meget mere synlige i den del af hiphopmiljøet, som når ud i danseskoler og træningscentre. Pigerne udtrykker oftest en meget stor og bevidst begejstring for hiphoppens anderledes måde at danse på. De kan lide den mere rå, frække og frigjorte stil. Den udvider nemlig også pigernes måde at være piger på, hvilket de er meget bevidste om, og alle har opsøgt aktivt. Polariteten mellem det maskuline og feminine i klassisk forstand er i høj grad udvidet specielt i hiphopdan- 
sen og måske især i den del af dansen, som betegnes som electric boogie. Electric boogie er den stilart, som tydeligst arbejder bevidst med at udvide klassiske maskuline og feminine udtryksmåder og nå helt nye bevægelsesudtryk. Her er tale om en høj beherskelse af hver enkelt lille kropsdel (separation) og en rytmisk timing, som både rummer det rå, det skarpe, det kontrollerede, som traditionelt forbindes med det maskuline udtryk og det nonchalent, det blide, det flydende, og det subtile, som traditionelt mere knyttes sammen med et feminint udtryk.

Hiphopkulturen er begyndt som et kreativt udtryk for oprør og overlevelsesevne i den amerikanske ghetto, et oprør, som udspringer af stærke, personlige oplevelser, og som i sin form og sin direkthed og sine anderledes holdninger ikke kan undgå at blive opfattet som farlig, på kanten af det nedbrydende og det forbudte, og derved vække angst og modstand. Pressen har i høj grad sat spot på denne side, fremhævet det farlige, det ukontrollable, det voldelige. Det er kvaliteter, der skræmmer og tiltrækker på én gang. Volden hører sammen med den amerikanske hiphopkultur, som er nøje knyttet sammen med gangsterbander. Det har medført, at vold er blevet kædet sammen med visse ydre hiphop tegn som f.eks huer og oversize bukser. Det har gjort det let at knytte associationen: Hiphopmiljøet er farligt. Men huer og oversizebukser er ikke længere tegn, der kun bruges af hiphopkulturens udøvere. De bæres af mange unge, også selv om de ikke i sig selv har noget aktivt forhold til selve hiphopkulturen. Det ændrer dog ikke på det faktum, at volden i det amerikanske hiphopmiljø, de rå tekster i gansterrap og graffittimalernes måde at vise sig selv og deres billeder på, ikke kan undgå at provokere og som sådan at blive et billede på, at hiphop- kulturen forbindes med farlighed, respektløshed og mangel på kontrol. Alt sammen tegn som automatisk ikke kan undgå at virke provokerende på samfundets normer og idealer.

Men hiphopkulturen er også en livsstil, der rækker langt ud over provokationen. Det er en international ungdomskultur, som overskrider ydre grænser og forskelle i nationalitet, $k ø n$, alder og race. De, som har været med længe, kender hinanden over hele verden. De sender videobånd til hinanden og er på den måde med til at inspirere hinanden, ligesom der også hentes inspiration fra dansevideoer fra MTV. Men idealet er hele tiden, at alle skal udtrykke sig med deres eget stof, på deres egen måde, udtrykke ting, som de selv har oplevet. Det skal ikke bare være imitation af idoler kendt fra medieverdenen.

Kulturen udfolder sig på gaden, i kældre, i ungdomsklubber og ved store festivaller, koncerter, på discoteker. Selv om de fleste inden for kulturen har prøvet næsten alle de forskellige udtryksformer og de forskellige stilarter, der findes etableret, så ender det tit med, at der sker en form for specialisering, fordi hiphopkulturen også har en professionel, kunstnerisk side, hvor spændvidden og nuancerne i det enkelte udtryk afhænger af en overraskende teknisk færdighed. Der er en kerne, som arbejder kreativt og fornyende, som er den egentlige undergrund i miljøet, og så er der en mere udvendig side, som er synlig gennem medierne og i den inspiration, der breder sig til en række forskellige områder, først og fremmest til den moderne rytmiske musikkultur og ud i ungdomskulturen som helhed og til moden, hvor elementer fra hiphopkulturen indgår mere eller mindre direkte og aktivt. Man efterligner kropslige attituder, tøjstil og slang. 


\section{Metode}

Jeg har først og fremmest haft kontakt med tre hiphopdansegrupper i København, nemlig Out of Control, New Funk og Back to Basics. Den ældste gruppe er Out of Control, og jeg har især benyttet lederen af denne gruppe, Sten, som en vigtig informationskilde om udviklingen af hiphopkulturen i det københavnske miljø siden starten i begyndelsen af 1980'erne. Jeg har foretaget gruppeinterviews med alle disse grupper og intensive interviews med Sten, Mark, Tonya og Pernille, alle meget aktive og kreativt fremtrædende personer i grupperne. Jeg har deltaget aktivt i deres træning og overværet deres undervisning af forskellige ungdomsgrupper og set deres danseshow på discoteker eller i forbindelse med ungdomsbegivenheder som f.eks underground modeopvisninger. Resultatet af disse kontakter med miljøet er en lang række indtryk og erfaringer, som jeg udtrykker i form af sceniske beskrivelser. Disse sceniske beskrivelser af oplevelser i miljøet sammen med indtryk fra samtaler og interviews er det materiale, som jeg benytter til at tegne et så nuanceret billede som muligt af de idealer, værdier og normer, måder at leve på, som kommer til udtryk i miljøet, idet jeg har lagt hovedvægten på hiphopdansernes miljø.

\section{Bevagelsesanalyse Kroppens fortallinger. Om at opleve bevagelse og dans}

Enhver bevægelsesanalyse må tage udgangspunkt i kroppen, rummet og tiden. Kroppen fortæller noget endnu før den overhovedet har bevæget sig. Allerede før bevægelsen - i kroppens form - har kroppen givet et tegn, et billede, som siger no- get om personen og om situationen, om vaner, mønstre og preferencer. Kroppen har allerede en fysisk grundform, alder, højde, vægt, køn, spændingsvaner, en holdning såvel fysisk som følelsesmæssigt, en udvendige påklædning, en øjeblikkelige energi og stemning. De grundlæggende spændingsmønstre former bevægelsesmulighederne og lægger sig som et ekstra skelet, bestemmer muligheder af former, linjer, ja de allermindste bevægelser, der ligger under de ydre former. Selve bevægelsesanalysen begynder jeg så åbent som det er mig muligt. Jeg lader de indtryk træde frem, som forekommer mig mest påtrængende og registrerer dem samtidig med de frie associationer, der måtte opstå. Som en hjælp til at være opmærksom på så mange elementer som muligt i situationen, anvender jeg Labans bevægelsesanalyse i en grundform, sådan som jeg har beskrevet det i artiklen »Musik og bevægelse « (Rønholdt \& Peitersen 1992)

Den kinæstetiske sans er af afgørende betydning for at opleve tingene 'indefra', idet den handler om vores evne til at indleve os gennem kropslig sansning i og imellem former og bevægelser, som vi er en del af. Denne evne til indlevelse er nødvendig for at få en nærhed i sansningen og dermed en balance mellem det indre og det ydre, mellem nær-og fjernsansning, sådan som især Søren Nagbøl har fremhævet det i sin forskning (1995). Evnen til indlevelse med opmærksomhed og sensitivitet er nøglen til vores måde at opleve på. Ved at indleve os i bevægelsen og mærke efter i vores krop, når vi meget tæt ind på tingene. Vores sanselige indlevelsesevnen og sensitivitet er afgørende for, hvordan vi oplever og fortolker kroppen og bevægelsesen i rum-tid og relationer. Billeder og sanselige, sceniske beskrivelser er det sprog, der bedst formidler en sådan oplevelse. Opmærksom- 
heden og sensitiviteten er afgørende for, hvor mange facetter og relationer, man er i stand til at opleve og beskrive.

I dans kan man sige, at den enkelte teknik og stilart formidler bestemte bevidsthedserfaringer, spændingserfaringer, bestemte stemninger og følelser og bestemte bevægelser, som igen bestemmer måden man sanser og oplever og bevæger sig på. Disse bindinger er såvel kulturelle som personlige, dvs, der er en vis fælles grundkode for forskellige kulturer, som så igen rummer personlige nuanceringer. Efter at være blevet trænet meget kontrolleret $\mathrm{i}$ en bestemt stilart og være vokset op i en bestemt kultur, som åbner og fastlåser kropsform og udtryk i ganske bestemte former, kan det være meget svært at ændre og nuancere måden man sanser, oplever og bevæger sig på. På en måde svarer det til, når man lærer at tale et fremmed sprog. Ofte kan man blive ved med at høre en vis accent. At opleve andre bevægelsesmåder er at udvide kroppens erfaringer - at lære nye udtryk og nuancer i kroppens nonverbale repertoire og dermed nye måder at sanse på, andre erfaringer og andre livsforståelser. Derfor er det vigtigt at bruge kroppen til at få en nuanceret forståelse af nye bevægelseskulturer, og det er dermed en nøgle til at forstå de tegn og signaler disse nye bevægelseskulturer rummer om nye potentialer såvel personligt som kulturelt. I Norbert Elias »The Symbol Theory « er der nogle generelle overvejelser om sproget, som også kan overføres på kropssproget. Kroppen er vores fælles biologiske fundament, men ligesom vi udvikler et unikt sprog afhængig af den kultur, og den historiske tid vi er i, udvikler vi også et unikt kropssprog, som afhænger af den kulturelle sammenhæng vi er i. Der er en universel basis af kropsudtryk som: at græde, grine, smile osv, selv om der er kulturelle og individuelle forskelle på, hvornår man gør hvad. Disse universelle menneskelige følelser findes i en uendelig grad af nuancer, som vi ikke engang altid kan beskrive verbalt, vi kan tale om et universelt rytmisk, poetisk kropssprog, som imidlertid også formes på baggrund af den enkeltes personlighed og livssammenhæng. Alligevel kan dette sprog tit forstås på tværs af kulturelle forskelle. Vi siger somme tider »at vi forstår hinanden uden ord«. Det er måske en slags kroppens esperanto. Både hverdagens bevægelser og dansen er begge udtryk for kroppen som symbolsk form og sansning. I hverdagens kropssprog er der altid en dimension af konkret handling, af situation og funktion udover selve stemningen, følelsen eller bevidstheden, som både spejler den ydre og den indre situation, både handlingen og 'de indre billeder' eller 'den indre stemme'. I dansen sker der ofte en abstraktion, hvor den ydre situation, handlingen ikke længere er vigtig - i stedet danses en stemning, en universel erfaring. Dansen er et symbolsk udtryk for krop, sanser, tanker og følelser, for måder at erfare og forstå livet på. Kroppen i dansen kan altså både være fortælling, poesi, billede og musik. Både i hverdagens og dansens bevægelser og kropssprog er kroppen bærer af universelle, kulturelle og personlige erfaringslag. Hvert enkelt menneske udvikler et særligt potentiale, en særlig rytme, en særlig stil karakteristisk for det menneskes erfaringer og personlighed, men disse erfaringer bliver virkeliggjort i den gruppe, den kultur, det samfund de udspringer fra. Måden de kommer til udtryk på er ikke medfødt. Den skal læres. Hiphop er et også et sådant symbolsk kropssprog.

\section{Hiphopdans}

I følge danserne i miljøet er der i virkeligheden slet ikke noget, der hedder hiphop- 
dans i hiphopkulturen. Hiphopperne foretrækker at betegne de enkelte dansestilarter mere direkte som break dance, electric boogie osv. Alligevel bruger de også selv udtrykket hiphopdans, som en overordnet samlende etikette, ligesom etiketten også mødes i musikvideoer, hvor koreografer fortæller om deres inspiration fra hiphopmiljøet eller fra 'streetdance', som det også kaldes. Hiphopdans rummer en blanding af mange forskellige udtryksformer, hvor dansen af udenforstående især forbindes med det akrobatiske break dance og det rytmiske electric boogie. Electric boogie hedder også boogaloo og dukkede op i 70'erne i Los Angeles. Det indeholder elementer fra discodans, showdans, step, jazz, mime med en meget sofistikeret isolationsteknik af hvert enkelt led i kroppen. De mimiske dele bliver ofte brugt til at fortælle små historier i et rytmisk, stiliseret kropssprog. Desuden indgår også slow motion teknikker, som ligner mimens. Electric boogie består af mange forskellige bevægelseselementer f.eks forskellige måder at gå på, af slow motion bevægelser, af specielle fodbevægelser f.eks 'moonwalking', gjort kendt af Michael Jackson i MTV. Moonwalking er en slags baglæns slæbefødder, som delvis svarer til en balletteknik, hvor der arbejdes med fodsålens fleksibilitet, en teknik som på engelsk kaldes 'brushes'. Hænderne kan have mange udtryk lige fra helt naturlige og afslappede til knyttede, forskellige gestus eller stiliseringer som f.eks ægyptiske hænder. 'Waves' er både bølger gennem armene og bølger gennem rygsøjlen og ud gennem armene. Bølgerne kan varieres, sådan at de bliver mere og mere opdelte i mindre og mindre led, som om bølgen passerer en uendelig række af led, hvad der kan være med til at forstærke det robotagtige, hvis det kombineres med stærke rykagtige mar- keringer af hvert lille led. Bølgen kan også udføres meget flydende, sådan at bevægelsen forplanter sig fuldstændigt organisk uden nogen tydelig afgrænsning i form af rykagtige, hårde akcentueringer.

Break dance rummer elementer fra brasiliansk kampdans, capuera og udvikles først og fremmes i gadens miljø i ghettoerne i New York og Los Angeles. 'Breaking' består af en række såkaldte 'style movements': 'Power moves' er tekniske, krævende $\emptyset$ velser som f.eks 'headspin', at snurre rundt på hovedet, 'swipes', en slags vandrette vindmøller, 'turtles', en balancestilling, hvor man går på hænderne, mens knæene er støttet over albuerne og kroppen er foldet ind som en skildpadde, 'freezies', slutpositioner, som skal falde præcist på 'beat'et f.eks i en 'baby', en vredet position med vægten på hænderne og 'combinations', alle mulige variationer og sammensætninger. 'Shuffle' er en måde at præsentere sig selv på, som egentlig bare består af afslappede trin ind i centrum af dansepladsen i musikkens rytme. 'Footwork' er meget store trin evt med een eller to hænder på gulvet eller helt ned på ryggen samtidig med, at man fortsætter med at holde musikkens rytme med fødder - altså 'footwork' i alle planer. 'Battle' eller 'opera' er de udtryk, som bruges om en form for symbolsk kamp/ konkurrence. Man viser hinanden i en form for rituel duel, hvad man kan med grundteknikkerne. Det er en form for leg, hvor det gælder om at have det sjovt, men også om at udfordre hinanden symbolsk og konkurrere. Det gælder om at bygge det gradvis op, sådan at der opstår en spændingskurve, men selvfølgelig også om at gøre det på en original og teknisk overbevisende måde. 
En scenisk beskrivelse fra

hiphopmiljøet:

Hiphopkonference $i$

Valbyhallen

fredag den 10. marts 1995

Vejret er fantastisk med strålende solskin, luften er krystalklar og alle farver og kontourer står lysende skarpt i det tidlige forårslys. Der er lange køer foran Valbyhallen allerede en hel time før konferencen skal begynde. Grupper af unge iført store hiphopbukser, forskellige uldhuer og kasketter og store sko eller støvler. Den fælles stil med meget løs og afslappet tøj, de karakteristiske uldhuer eller kasketter, de store militærstøvler eller sportsst $\varnothing v l e r$ giver overfladisk et fælles udtryk, en slags udvendig gruppeidentitet, uden at det på nogen måde giver nogen perfektionistisk fornemmelse af, at det skal være lige på én bestemt måde. Næsten ingen står stille. De fleste hopper lidt frem og tilbage eller op og ned og bokser hinanden venligt. Taxaer ankommer af og til med udlændinge, der formodentligt skal indgå i konferencen på forskellige måder. Endelig bliver vi lukket ind, dog først efter at være grundigt kontrollerede for våben af kæmpestore, muskelsvulmende vagter, med maskinklippede hoveder. Det giver en noget speciel stemning. Klokken er kun fem om eftermiddagen og i følge annonceringen skulle konferencen begynde nu. Det er der dog ingen tegn på. Der bliver heller ikke givet nogen oplysninger. Alle traver bare frem og tilbage i forhallen uden at vide, hvad der skal ske.Ventetiden fordriver jeg med at se mig omkring. Der er ikke nær så mange piger som drenge. De piger der er, er enten i de traditionelle store bukser, ligesom drengene, eller de er i korte shorts og mørke nylonstrømper. Håret er ofte formet $\mathrm{i}$ kunstfærdige fletninger med tydelig afroinspiration, nøjagtig som man kan se det i »The Source«, et amerikansk tidsskrift for hiphop, som også kan købes særlige steder i København f.eks i kiosken i Yorks Passage.

Konferencen begynder med en god times forsinkelse. Raymond Greer, en 40årig amerikansk tidligere bandeleder fra Los Angeles lægger ud i en meget direkte, dynamisk stil:«Have some of you been raped? (latter) Have some of you been a rapest? Why are you not laughing now? Are some of you on drugs? Have your stepfather touched you in a wrong way? Have your mother touched you in a wrong way? Have your father touched you in a wrong way? Have your uncle touched you in a wrong way? Have you been drunk? Have you said to yourself. Oh I feel bad. I can't go to school. Have you done that? Have you done it? Have you stabbed someone? All I want you to know, you are not alone.You all want to be loved? You know what love means? Love has no colour. Vi er her ikke for at synge eller for at prædike. Det er ikke tøjet, der gør dig til en cool hiphop'er. Vi må gå ud over filmens forbilleder. Vi behøver ikke vælge samme livsstil som på film. Vi behøver ikke være som alle andre. Hvis I tror vold er en del af rap og hiphop, så leger I med ilden. Får tøjet jer til at føle jer 'cool'? Husk, at det kun er en kunstnerisk udtryksform. I må ikke tage det bogstaveligt. I er ansvarlige for, hvad I gør, vælger, hvad I lytter til? I vælger, hvad I tager på? Find nogen, du kan stole på. Tal med dem. Måske i organisationen 'Stop volden'. Mit virkelige problem var slet ikke stoffer og alkohol. Mit virkelige problem var et livsproblem. Jeg var angst. Jeg turde ikke invitere en kvinde ud. Derfor tog jeg stoffer og alkohol, for at få mod til at invitere en kvinde ud at danse. 
I Los Angeles har mentaliteten ændret sig. Vi prøver at hjælpe hinanden. Det at være i bander og at være voldelig har udspillet sin rolle i USA. I prøver bare på at gøre noget, som allerede har været gjort. Kærlighed har ingen farve. Vi føler, at vi må beskytte os selv. Vi prøver at se det gode i et andet menneske. I skal give udtryk for jeres følelser, men ikke på en voldelig måde. Racisme har heller ikke nogen farve. Det starter inden i hver enkelt af os. Lad os se ind i os selv. Vi må være aktive i freds bevægelser, i ‘Stop volden' bevægelser. Det kræver, at vi går sammen om at løse problemerne. Det nytter ikke at have fordomme over for det ydre. En er for tyk. En anden er for tynd. Hun er for affarvet. osv. I behøver ikke gentage det, vi gjorde. «

En dansk rapgruppe, 'Upskiboo', indtager scenen med energi og et temmeligt stereotypt kropssprog. Deres bevægelser er enkle, firkantede, hårdtslående. Kroppen holdes hele tiden lidt foroverbøjet, kompakt uden bevægelser i ryggen. Armene pumpes symmetrisk op og ned som rytmiske non-stop billeder fra sportsverdenens ekstatiske sejrssymboler. Lydniveauet er højt, smerteligt højt, synes jeg. Svingningerne fra bassen trykker kroppen sammen i kraftige rytmiske ryk. Der er masser af lyspåvirkning. Hurtige lyskegler skifter op og ned i rytmiske bevægelser. De to rappere traver frem og tilbage over scenen, mens de støder deres tekst frem, afbrudt af hyppige opfordringer som: »Say adoo«. »Wave the hand." Alle følger opfordringerne. Der bruges også en kraftig røgmaskine, som indhyller scenen i svulmende, lysende skyer. Opvarmningen fortsætter med gentagne, rappende opfordringer: »Say hoo«. »Hoo, « ekkoer massen. »Say Ho, Ho, Ho.« »Ho, ho, ho, « lyder ekkoet veloplagt. »I want to see sombody jump. Come on. »Lyset skifter op og ned og for- stærker følelserne af oppisket, ekstatisk energi. Alle hopper i takt til de to rapperes dirigerende armbevægelserne. Bevægelserne er meget stereotype. De bevæger sig henover scenen med lange skridt og skarpe retningsskift, mest frem og tilbage og fra side til side. Bevægelserne afbrydes kun af aggressive boksestød opad med én arm. Bevægelsen gentages i det uendelige. Det er ikke dansebevægelser. Det er snarere agitatorens hypnotiske gentagelse: Enkle, insisterende, korte, direkte, opfordrende gestus. Men også gestus, der udtrykker en aggressiv, begejstret, kamp energi. En form og en energi, der spejler en klassisk manderolle, der bruger lederens og gruppeforførerens hypnotiske og agiterende kropssprog.

Derefter fulgte en kortere pause med opfordring til at respektere stedet og ophøre med graffiti, som der allerede var fundet flere steder, både på toiletterne, på gangene og på gulvene.

Ved 21 tiden om aftenen begynder der at komme lidt flere piger til. De fleste piger er nu iført sorte hotpants med hvide adidas striber, sorte tynde nylonstrømper og sorte adidas sko med hvide striber.

Grandmaster Flash, Melle Mel \& The Furious Five, en kendt amerikansk rapgruppe indtager scenen med autoritet. Melle Mel er iført løse, store afslappede blå cowboybukser og en lys brun læderjakke, brune militærstøvler og en grøn rygsæk. De fortæller, at de lægger vægt på positiv rap og at oprindelig begyndte hiphop altid med en fest. Grandmaster Flash er en mørk fyr i træningst $\varnothing j$ og en meget original hovedbeklædning. Han har bundet et sort slør stramt om hovedet og hestehalen er fremhævet med et bredt guldbånd, som er flettet uden om sløret. Jeg har været break dancer, forklarer han, men nu holder jeg mig til rap, ellers ville jeg nok komme til 
skade. »I skal tænke på, hvad I vil med jeres liv? Tiden går hurtigt. For tre dage siden var jeg i jeres alder. Mit bedste råd til jer er, at I skal holde jer væk fra folk, som gør onde ting. Vær en leder, ikke en, der følger. Få jeres egen stil. Har I hørt om Karmaloven. Karma betyder, at alt det I gør kommer tilbage til jer. Derfor må I prøve at gøre gode ting. Ice T er bare en almindelig fyr ligesom mig. De er almindelige mennesker. De har familie og børn, som de prøver på at tage sig af. De agerer bare. I skal ikke bare efterligne dem. I skal være jer selv. Gøre tingene på jeres egen måde. Prøv aldrig på at være ligesom naboen ved siden af jer. I må arbejde hårdt. Det er hårdt at tage sig af en familie, at forsørge den, at tilberede måltider, at købe ind, gøre rent. Undgå at gøre skade på nogen.

En del rastløshed og pauser. I pauserne sidder folk på gulvet i smågrupper. Enkelte dansetrin ses til musikken som sendes ud over anlægget. Rundt omkring står der smågrupper, der ryger, snakker og griner. Alle drikker cola, $\varnothing$ l eller juice af kæmpe plastikbægre. Efterhånden ligger der lag af knuste plastikbægre på gulvet og masser af cigaretskod. Lyset i pausen er uklart, farverne bliver gulgrå, lidt snavsede. Det hele får et træt, håbløst udseende, som om publikum lydløst udtrykker en fælles oplevelse af tomhed, kollektive billeder af 'alt er ligegyldigt, det betyder alt sammen ikke noget'. Ud over anlægget strømmer ordene »'ve got to be me«. Er det en opfordring? Er det ironi? Der er ingen tvivl om, at det er ment som en opfordring. Lagene af plastikkrus og cigaretskod er blevet stadig højere, og der er også dukket nye beskedne fors $\emptyset \mathrm{g}$ på gulvgraffiti op. Anlægget rapper løs. Der er små antydninger af dansetrin i det gulgrå, snavsede lys. Stemningen er mat, afventende. Jeg kan ikke ryste indtrykket af en destruktiv ligegyldighed af mig.
Der kommer flere unge piger. De lyser op i lokalet. Deres udstråling er nu klart mere bevidst sexet. De piger, der nu kommer, er klædt i mere kropsafslørende tøj: Hot pants. Mininederdele. Højhælede støvler eller som kontrast til de tynde sorte nylonstrømper, kæmpestore sorte militærstøvler. Håret er enten ultrakort eller kunstfærdigt flettet eller bæres som langt, lyst havfruehår. Det sidste går øjensynligt aldrig af mode.

Melle Mel \& The Furious Five fortsætter efter pausen med at piske gruppeenergien op. Min umiddelbare tanke er, at en Hitler kunne ikke have gjort det med større effektivitet. De går langt frem på rampen og med en energi og målrettethed henvender de sig direkte til massen. Gruppen begynder at bevæge sig som ét individ - ét kor. Og Melle Mel \& The Furious Five dirigerer koret. Enkle kropsbevægelser og råb gentages i en rappende, fælles rytme. Lysshowet intensiveres og forstærker den rytmiske hamren. Lyskegler fejer henover scenen og publikum, skærer røde, blå, hvide lyssøjler henover scenen, igennem rummet, igennem gruppekroppen. De får mængden til at hoppe synkront, med armene løftede op over hovedet. Massen er ét med rytmen, ordene og gestus fra The Furious Five. Lydniveauet er over smertegrænsen, men formodentligt har de fleste for længst passeret normal sansning, og dermed også passeret enhver registrering af normal smerteoplevelse. Alle ser ud til at være forsvundet ud i en fælles gruppeekstase. Ord, bevægelse, lys, lyd og rytme - alt hamrer en fælles udgående, ekstatisk puls.

Man kan få en lille pause ved at bevæge sig ud i forhallen. Her er støjniveauet dæmpet til en hård, rytmisk hamrende baggrundslarm. Set ude fra forhallens lys ligger salen i kulsort mørke, kun oplyst af lyskeglerne, der slår rytmen ind mod net- 
hinderne og den elektriske bas, der trykker mellemgulvet sammen og de rappende stemmer, der suverænt bestemmer massens råb og bevægelser. Sætningen »Don't be a follower. Be a leader « runger svagt i mit hoved,overdøvet af de stadigt hurtigere »Say Ho.« »Ho«. »Say ho, ho, ho«. »Ho, ho, ho, « lyder ekkoet.

\section{Anden sceniske beskrivelse fra hiphopmiljфet: Hiphopgruppen New Funks traening oppe under himlen, i Scala, 22. Juni 1995}

Jeg spadserer gennem H.C. Ørstedparken og derfra gennem Latinerkvarteret i retning mod Scala, et kæmpeindkøbscenter og mødested i centrum af byen med caféer og træningslokaler $\emptyset$ verst oppe. Jeg står med næsen vendt mod den bolchefarvede paladsagtige bygning over for Palads. Når jeg ser på den, får den mig altid til at smile på grund af alle de glade farver, som man ellers kun kan forestille sig dem i en eventyrverden, hvor husene er bygget af farvet sukker. Jeg er i meget god tid før den aftalte mødetid med hiphopdansegruppen, New Funk, hvis medlemmer på dette tidspunkt er lederen Mark, som lige er 20 år og hans to meddansere Søren og Micky, 16 og 15 år gamle, såkaldt 2. generations hiphoppere. Jeg skal overvære deres træning til et show på et discotek fredag nat i Farum. Jeg ved, at der også skal komme nogle piger til denne træning, Michala og Pernille. Jeg går ind i Scalabygningen, i stueetagen og forsøger at orientere mig lidt. Det er vanskeligt. Larmen er overvældende. Musikken drøner ud af højtalere fra alle mulige steder. Og naturligvis forskellig musik på een gang. Det er ubeskriveligt. Det samme gør sig gældende med duftindtrykkene, der blandes ligeså umuligt. En vammel duft af popcorn vælter imod mig, men den blandes hurtigt op med stærke krydrede, italienske dufte, som igen blandes med friturestegt fiskeduft osv. Kaotisk. På samme måde med rummene. Jeg mister faktisk retningsorienteringen, fordi alle rummene flyder over i hinanden. Alt er trangt, snævert og overfyldt og flyder ind over hinandens grænser, samtidig med at alle også prøver at markere sig og afgrænse sig mest muligt. Mit største $\varnothing$ nske er at finde et sted, hvor der er én stemning, kun én musik ad gangen, kun én slags duft, ét rum, ét punkt, hvor man kan lade sin opmærksomhed hvile. Det lykkes ikke. Ser jeg mig omkring, er det tydeligt, at det stort set kun er meget unge mennesker, som slentrer rundt eller sidder og hænger på caféstole eller barstole. De ser alle fuldstændigt afslappede ud, og som om de har uendelig god tid. Det, der for mig føles lidt som en krigszone, et bombardement af alle sanser, ser ud til at være ungdommens Mekka. Jeg forsøger at overgive mig til mangfoldigheden af sanseindtryk. Det giver en flimrende fornemmelse af støj, lyd, lugt, synsindtryk, stemmer, mennesker, mad, $\varnothing 1$, reklamer, lys. Det er overvældende. Jeg fornemmer at måden at overleve på, er at flyde af sted og give slip på al modstand og acceptere, at alle disse sansninger bare er der. På den måde lykkes det mig at holde mig fritsvævende midt imellem alt, uden at fæstne mig ved noget bestemt. Det opleves som en flydende tilstand, hvor lyde, dufte og lys bliver til en slags bølger, som nok rører ved mig men alligevel ikke berører mig. Blikket flyder ud og forsvinder i mellemrummet mellem alt og intet.

Fitness Club ligger på 5. sal. Jeg er stadig $i$ alt for god tid og håber alligevel at finde et lidt roligere hjørne, hvor jeg kan samle mine 
tanker. Oppe under glastaget ligger der en café med kurvemøbler. Lyset er meget smukt. Stemningen virker mere dæmpet, selv om der også her er i hvert fald to forskellige slags musik, der mødes på én gang. Der er også lysreklamer fra baren lige ved siden af, som skærer neonrøde linjer gennem de ellers vægløse, udefinerede rum. Taget er åbent op mod aftenhimlen. Himlen er dyb blå med mørke, blyfarvede skyer. En stor, smuk og dyb himmelvælving i skarp kontrast til det menneskeskabte rum, hvor det fælles uudtalte og allerede opfyldte $\varnothing n$ ske ser ud til at være 'lad der endelig ikke blive stille eller tomt rundt om mig'. Terrassen er stort set tom for mennesker. Det blæser kraftigt og lyden af vindst $\varnothing d$ blander sig med lyden af stemmer og flere forskellige slags musik. Det giver en meget speciel stemning med denne sammensmeltning af det uendelige himmelrum og lyden af blæsten og de hektiske rum, hvor alt udbydes og støder sammen på én gang.

Jeg begiver mig det sidste stykke op til Fitness Club for at finde New Funk hiphopdansegruppen. Mark er der allerede, og han introducerer mig for sine venner. Jeg daler ned i et hjørne. Salen er ret lille, men meget smuk og stemningsfuld. Hiphopmusikken drøner gennem rummet, men uden andre musikspor kørende samtidig. Det giver en stærk pulsrytme i rummet. Lyset er meget smukt. Salen er fuldstændig dækket af spejle på de to vægge, mens den ene langside og taget er vinduer. Vinduerne står på klem og en gang imellem rammes jeg af et par regndråber. En ung mand er allerede i gang med at afprøve nogle hiphopdansetrin. Han viser mig en temmelig svær nedgang til gulvet. Den er krævende og bagefter stønner han og siger, at han faktisk ikke er smidig nok til den. Endelig ankommer pigerne også. De hilser på mig, og fortæller at de også skal interviewes næste dag til Ra- dio Uptown. Derefter går de straks igang. Der er ingen formelle opvarmningsritualer. De går direkte til trinene i deres dans. Rummet fyldes af deres energi og danseglæde. De er gode, meget gode endda. Der er tempo og dynamik i bevægelserne. Stilen er funky, fræk, nonchalent, overraskende, stædig, med armgestus, øjenbevægelser, skarpe hovedbevægelser. De kommer helt ned i gulvplan og hurtigt op igen. Der er masser af dansetrin og retningsskift med den evige elastiske op og ned rytme. Rytmens kontinuerlige flow brydes skarpt $\mathrm{i}$ korte øjebliksfotos, som de kalder 'locking'. Der er fart på, masser af energi, masser af charme. Stilen rummer også nogle spændende og overraskende kontraster. De veksler mellem at bruge kroppen meget mekanisk med helt låst hvirvelsøjle, hvor kroppen fungerer, som om den var en robot for så at bryde og bruge en fuldstændig organisk gennemløbende bølge, stadig i den evige pumpende puls. Det er tydeligt, at de har god kontakt i gruppen. De kører en slags kollektiv instruktion, hvor de med ultrakorte bemærkninger fastlægger tvivlsspørgsmål i koreografien. Der er også et par passager, hvor de arbejder sammen i par, et $\varnothing$ jebliks fysisk kontakt, som hurtigt opløses i føddernes og kroppenes pulsrytme. Koreografien er meget præcis, fuldstændig fastlagt, båret af den kontinuerlige puls. Skarpe stop får rytmen til at rykke og overraske. Det svinger. Gruppen er meget bevidst om den stil, der kommer til udtryk med deres bevægelser. De kigger kritisk i spejlet og kommenterer: »Nej, det er for feminint. Vi må bøje mere i albuen. Det er mere sejt. « De bruger meget afslappede og knyttede hænder og ind imellem en genkendelig gestus, som bruges uventet eller i en uventet sammenhæng, hvad der giver bevægelsen en overraskende og humoristisk virkning. Hovedindtrykket af stilen er, 
at den er meget afslappet samtidig med, at den har en ultrahøj energi. Det kommer bl.a. til udtryk i elasticiteten, spændstigheden, som hele tiden er nødvendig for at kunne holde den kontinuerlige, rytmiske op-og nedadgående fjedren i benenes forflytninger. Der er også andre kontraster f.eks i brugen af rummet, hvor der indgår mange retningsskift. Koreografien indeholder kun lige retninger: Lige til siden, lige frem, skarpe drejninger. Til gengæld er linjerne i kroppen ikke lige, de er skæve, overraskende, brudte, afspændte med bevidst brug af isolation, hvor enkelte kropsdele accentueres tydeligt. Der er bevægelse i alle led, som næsten aldrig er gennemstrakte. Der kan være et højt bensving med flekset fod og strakt knæ, men ellers er fodled, ankelled, knæled, hofteled, talje, skuldre, albuer, håndled, hænder, afslappede, samtidig med at de rummer en aggressiv energi, klar til at eksplodere ud i lange rytmiske kaskader af trin. Danserne er allerede efter 20 minutter gennemblødte af sved. De puster hørbart. Det er tydeligt, at dansen er krævende rent intensitetsmæssigt. Øjnene stråler. De smiler. De kontinuerlige hop ser ud til at have en euforiserende virkning på dem. De er klar igen. Dansen fortsætter. Musikken fortsætter. Rytmen fortsætter. Non-stop. Jeg går derfra med en følelse af, at jeg svinger med i den samme rytme, en rytme, som både understreger tiden og opløser den.

\section{Tredje sceniske beskrivelse: Tonia er gastelaerer $i$ Hiphop på Stepz Dansestudio torsdag d. 15. juni 1995}

Tonia kommer ind i Stepz dansestudio, den store træningssal. Den ene væg er udeluk- kende store vinduer. De to andre er helt dækket af spejle. Der er anbragt nogle nye farverige pudeskamler i knaldgult, violet, grønt og turkis langs søjlerne. Tonia kommer ind iført en løs, lysegrå bomuldstræningsdragt og en lys grå t-shirt i overstørrelse. Hendes hår er meget lysegult, i tætte korte afrokrøller i reggae stil. Hun er mulat. Kontrasten mellem hendes gule afrokrøller og den chokoladegyldne hud er iøjnefaldende. Hendes udstråling er smuk, afslappet, lys og glad. Hun læner sig smilende op ad søjlen ved musikanlægget og begynder timen med en beroligende kommentar om, at alle sagtens kan følge med.

Hun begynder timen med at bevæge sig i nogle meget langsomme, næsten statiske stående strækøvelser til langsom, rytmisk musik. Hun bevæger sig med ryggen til os, men ser os i de store spejle. Kroppe bøjes, strækkes og drejes i enkle klassiske stræk, ben strækkes alt sammen meget langsommere end det det ofte gøres og til langsomme, funky rytmer. Det er en sjov kontrast med de glidende, lidt drømmeagtige bevægelser sammen med musikkens bankende rytme. Det fremhæver oplevelsen af pulsen i de glidende bevægelser. Tonias udførelse er organisk og strømmende. Hun bevæger sig som en sensuel kat. Hendes udstråling er stærk, på én gang fræk, drenget, men samtidigt også meget feminin uden brug af traditionelle ydre, feminine signaler. Hendes tøj er enormt stort og hullet. Hun er helt uden make-up og smykker. Men begge dele fremhæver hendes egen krops udstråling af ynde og elegance. Hun bevæger sig med stor styrke og selvtillid. Stilen er meget kraftbetonet, hendes skridt er lange, der er en enorm energi i hendes bevægelser. - Alligevel er indtrykket af hende meget feminint, men en moderne femininitet, der udstråler initiativ, handlekraft og styrke samtidig med en intens sen- 
sualitet udtrykt gennem hendes krops meget nuancerede koordination med en enorm spændvidde mellem afspænding og spænding mellem beherskelse af den enkelte kropsdels isolerede udtryk og samspillet af helheden i rytmen og bevægelser, der på overraskende måde blander det flydende og det skarpe og hårde. En bevægelsesstil, som udtrykker sensualitet og høj energi, især i kraft af kroppens centrum, som bevæges på en både aggressiv og rytmisk magtfuld måde samtidig med, at den er sensuel og indfølende. Tonias kropssprog ser ud til at være udsprunget af en udvidet femininitet, der overskrider stereotype kønsroller og også stereotype normer for, hvad der er smuk bevægelse.

Så begynder første rytmiske dansetrin og lidt efter lidt bygges en hel lille serie op. Tonia lover, at vi nok skal blive vågne og varme. Tempoet er først langsomt markeret ca 6 trin pr 5 sekunder. Senere stiger tempoet til ca 8 trin pr 5 sekunder. Ikke noget vildt hurtigt tempo, men alligevel med en synkoperet (funky) rytme, som understreger følelsen af, at alt er i flydende pulserende bevægelse. Intet er stivnet. Offbeat'et udnyttes, idet bevægelserne ofte begynder eller fremhæves på $» 0 \mathrm{o} «$. Tonia beroliger alle, både med sin udstråling og sin afslappede kropsholdning, men også helt konkret ved at understrege, at hvis det ikke lykkes, gør det ikke noget. Det er o.k. at udføre bevægelserne lige på 'beat'et. Tempoet stiger. Sveden driver. Smilene breder sig. Vi fortsætter dansen i tre kvarter, stort set uden pauser - kun et enkelt stop med spørgsmål og forklaringer.

Lektionen slutter med meget langsomme, næsten statiske stræk til rytmisk musik. Serien er typisk funky, hiphopstil. Hovedvægten ligger på den markerede rytme. Rytmen udtrykkes først og fremmest med fødderne, knæene, men hovedet, hofterne, kroppen og armene understreger rytmen på samme markerede måde. Det er en enkelt serie på begynderniveau, og derfor er der heller ikke tale om nogen kompliceret separation af forskellige kropsdele. Der er dog en enkelt kropbølge, som kommer fra en bred hugsiddende stilling. Netop denne bevægelse er både sensuel og indfølende og samtidig udfarende og kraftbetonet. Udtrykket er netop, som Tonia betoner det: råt og sexet eller kort og godt funky.

Efter lektionen samles vi i omklædningsrummet og bemærkningerne ryger spontant rundt i lokalet uden nogen bestemt adresse. »Det var helt anderledes end almindelig fitnesstræning. « »Det var sjovere.« »Man fik sved på panden.«»Det gjorde ikke ondt. « » Det gør fitness. « »Fitness er mere ren styrketræning for maven osv, hele kroppen bliver gået igennem.« $»$ Det er mere rutinepræget, men det er effektivt.«»Det er ikke så sjovt, som det her var.« »Man skulle nok gøre begge dele.«

Fjerde sceniske beskrivelse: Kropsbilleder fra en ungdomsscene. En analyse fra Celebration of Youth Event, lordag den 30. september 1995. Pakhus 11

Publikum er begyndt at komme. Der er rigtig mange. De står i smågrupper, med blikket rettet udad over et stort bæger fadøl og iagttager delvist skjult bag cigaretternes tynde røgspiraler. Rummet er stort og åbent med kæmpelys-og højtaleranlæg. Væggene er hvide og ellers er alt gråt og sort. Der er en charmerende, rå stemning med en dramatisk belysning af kæmpespots og af og til lysshow i neonfarver på skærme højt oppe på væggene. Belysnin- 
gen giver en kraftig kontrast af lys og skygger, hvad der gør ansigter og kroppe meget skulpturelle.

En ung fyr sidder oppe på den ene lange scene og spiller blød jazz à la min fars ungdom fra 30'erne. Master Fatman, en moderne popbuddha, iført hvid smoking og hestehale traver rundt og hilser.

Master Fatman træder ind på den lange scene med en høj, tynd model, som han holder i hånden. Hun er iført ultrakort, lægget nederdel i lysegrøn neonfarve à la tattoo stil og et kæmpeafrohår og bærer en kraftig make-up med tykke sorte streger om øjnene. Læberne er knaldrøde. Hun stirrer ud i luften, og man får et indtryk, som om hun slet ikke er levende, men den perfekte barbiedukke i kæmpeformat. Master Fatman sætter sig i en kæmpestor lænestol i læder, der fungerer som tronstol. Han byder velkommen med afslappet smalltalk og varm kosmisk hilsen. Barbiedukken står ubevægeligt bagved lædertronstolen som en dekoration.

Publikum er klædt outreret på. Utraditionelle frisurer og hårfarver, som påkalder sig opmærksomhed. Pigerne er i meget kropsnært tøj, ultrakorte nederdele, stumpede bluser med et stykke nøgent maveskind. Fyre i alle stilarter fra almindeligt blødt cowboy t-shirt look til enkelte unge mænd i en slags 'dandy stil' med elegante figursyede frakker i nålestribet og kridhvide skjorter med kæmpeflipper og store, lange kravespidser. Der er også mange sorte læderjakker og cowboybukser.

Alle slags skarpe hårfarver findes, også bordeau og blågrønne vekslende med kulsort og meget lyst platinblondt hår. Håret kan være langt eller ultrakort, gerne i geometriske linjer eller helt skallet. Avantgarde papillotter i grønt og blåt i ultrakort hår får hovederne til at se ud som en slags tegneserierobotter og understreger det farve- strålende technolook. Der er også enkelte unge mænd med bløde krøller i halvlangt hår og en del piger med langt udslået hår. Pigernes make-up er meget kraftig, gerne i skærende farver såsom lyserøde øjenskygger indrammede af tykke sorte, blå eller violette kohlstreger. Læberne er tykt optegnede med blank, mørkerød eller blåviolet læbestift. En mode der frem for alt fremhæver kroppens overflade og kroppens linjer og former - men som også er med til at fastlåse kroppens bevægelse. En mode som lader kroppens centrum - talje og navle - være nøgne. Et signal om frihed og sanselighed, men et signal, der modsiges af den stramt kontrollerede form, hvor intet får lov til at komme til spontant udtryk.

Alle har travlt med at se sig omkring ikke nødvendigvis særligt optaget af, hvad der foregår på scenen, snarere optaget af hinanden, af forbipasserende og af sig selv.

I den store, stemningsfyldte hal, med den rytmiske musik, det spændende lysshow og den store menneskemængde er der ialt tre små tilløb til dans. Alle meget 'cool', tilbagelænede og stadigvæk med den uundværlige cigaret som vigtigste signal om, at man er 'cool'. En enkelt mand svinger henført til musikken og ser ud til at være forsvundet ind $\mathrm{i}$ en tranceagtig tilstand. Kun to par antyder lidt dansetrin. En pige med en ultrakort nederdel med sortbroget »komønster« og bar mave, bordeaufarvet hår og øjne omrandet af tykke eyeliner streger danser med en fyr iført nålestribet i en slags »dandy«stil med hvid skjorte med kæmpekrave. De svajer lidt frem og tilbage til musikken - begge med den tilsyneladende uundværlige cigaret i hånden. Et andet par danser let tilbagelænet over for hinanden, mens de begge holder cigaretterne svævende imellem sig. Ellers er der kun stillestående grupper, småsnakken- 
de med øjnene i alle retninger. Der er mærkeligt nok heller ingen fysisk kontakt. Der er ingen som rører ved hinanden eller giver hinanden et kys eller har intens øjenkontakt. Alles øjne er rettet udad i en stadig iagttagende søgen. Overfladen er kontrolleret, iagttagende og iøjnefaldende. Man er der for at se og for at blive set. Lydniveauet er så højt, at det er vanskeligt at føre en samtale. Det er en musik, der opfordrer kroppen til rytmisk udfoldelse, men alligevel er der næsten ingen, der bryder den iagttagende stil, som karakteriserer bevægelsen i rummet.

Fejende lyskegler og to store lysskærme med vekslende lysbilleder, hvor bevægelserne fra lysshowet sammen med musikken giver et sandt bombardement af sanserne. Scenen er kunstig og så outreret som mulig. Showet kan hele tiden følges på kæmpefjernsynsskærme, hvad der yderligere understreger følelsen af at være tilskuer. Det er afslørende at se, hvordan ham der styrer videocameraet kun focuserer på den musiker eller sanger, der har soloen. Han overser fuldstændigt de andre bevægelser på scenen f.eks samspillet mellem basspilleren og orglet, som indeholder meget lune og øjenkontakt.

\section{Modeshowet}

Derefter begynder underground modeshowet, som måske er hovedevent'en. Modeshowet er endnu mere lak, læder plastik og kunstigt hår og outreret make-up end publikums egen iscenesættelse.

Master Fatman introducerer entusiastisk, at det er den ny tids kommende designere, den ny tids mode vi vil få at se, det, der om få år vil koste oceaner af penge.

Modellerne ser alle ud som plastikbarbiedukker i en science fiction film. Modeshowet er i neonfarver - æblegrøn, kirsebærrød, babylyserød, skinnende laksort og skinnende plastikhvid. Stofferne ser ud som en slags voksdug. Snittet er midt imellem rokoko, science fiction og tegneserie. Mest karakteristisk er, at alt er meget kropsnært, med bare maver, bare armhuler og evt helt bar overkrop kun iført bodypaint. De fleste af kostumerne ser ud til at være umulige at sidde i eller for den sags skyld at bevæge sig $\mathrm{i}$ - for slet ikke at tale om at danse i. Skoene er en form for skulptur, stive, med meget høje hæle eller plateausåler, nærmest som sokler, der løfter bæreren op på en piedestal, - altsammen medvirkende til at give et indtryk af 'ophøjethed', fjernhed fra massen, i bogstaveligste forstand figurer hævet over det normale gulvniveau og frem for alt kronet af udtryksløse maskeansigter med tomme, fjerne $\varnothing j n e$. Døde figurer i et vokskabinet. Den opstyltete, højtidelige fremadskridende stil - en stil, som giver associationer til billeder fra det gamle franske hof og høviske omgangsformer - understreges af kvindernes kunstfærdige frisurer og outrerede hovedbeklædninger, der enten gør personen højere eller også fungerer som en slags halvmaske for ansigtet. Det perfekte plastikmenneske renset for livets normale uforudsigelighed, bevægelser, følelser, rynker og udtryk. Menneskeidealet som fuldstændig lydefri voksskulptur, fri for spontane livstegn og uden smålige hensyn til føddernes eller kroppens evt længsel efter at kunne bevæge sig flydende og frit, grine, græde bevæge sig og blive bevæget. Modellerne skrider adstadigt og tilbagelænet ned ad podierne til rytmisk technomusik. De drejer rundt som på en drejeskive, står lidt, stirrer fjernt ud i rummet og forsvinder så. Kun én model bryder mønsteret. Hun er vanskelig at bedømme, idet hun virker som en transvestit overdrivelse i et dragshow. Iført et 'femme fatale' kostume i rødt skrider hun dramatisk frem som 
om hun bliver transporteret på hjul for til sidst at stoppe dramatisk op og se direkte ud på publikum. Hun holder en kort, åndeløs pause. Publikums opmærksomhed skærpes, og da hun bryder ud i en kort sang med en karakteristisk, dyb sensuel stemme midt imellem mand-kvinde svarer de med spontane klapsalver. Straks efter forsvinder hun ligeså glidende og lydløst som alle de andre modeller ud bag et forhæng.

Endelig er scenen ryddet og sidste scene kan begynde, nemlig danseshowet med hiphopgruppen Out of Control.

\section{Out of Control, hiphopdansegruppe}

Master Fatman annoncerer gruppen som Old School electric boogi'er og break'ere.

Så meget rytmisk energi på så lidt plads. Ufatteligt. Så megen dynamik, fleksibilitet og præcision. Trommerne understreger $\mathrm{i}$ høj grad den direkte, fysiske energi, der ligger i dansen.

Sten begynder showet i fuldendt rytmisk kontrol. Hver lille del af kroppen artikulerer raffineret i en kontinuerlig strøm af stop og flow. Derefter følger en rap dans med en mørkkrøllet fyr, som jeg ikke er blevet præsenteret for. Derefter en duo i vanvittigt tempo med en ubeskrivelig energiudladning fra Sten og Henrik. Kenneth break'er og til sidst danser alle på scenen, selv trommeslageren Peter, som helt tydeligt ikke er vant til at stå på dansegulvet $\mathrm{i}$ et show. Iscenesættelsen er enkel, beigegrå fangedragter med ens små huer. På ryggen står Dr Psyko. Det hele sluttes af Sten med en raffineret 'Moonwalking'.

Som sædvanlig er jeg fuldstændig betaget af deres bevægelseskunst, som efter min opfattelse er suveræn og så raffineret, at jeg ikke kan undgå at blive overrumplet, fascineret og indfanget. Når jeg ser på dem, gennemstrømmes jeg af en uforklarlig elektricitet, en ekstatisk følelse af at være levende, vibrerende, en følelse som gennemstrømmer min krop og helt bogstaveligt får hårene til at rejse sig i fryd. Jeg gennemstrømmes af en følelse af, at jeg svinger med i deres pulsrytme, der på en gang både understreger tiden og samtidig opløser den.

\section{Analyse af hiphopdansen sådan som \\ Out of Control udfører den}

Disse hiphopdansere illustrerede med deres bevægelser en høj grad af kontrol og en lige så høj grad af frihed i nuanceringen af kroppens potentialer. De har en gestik og et mimisk udtryk, der ligger midt imellem barnets forundring, den voksnes frustration og klovnens stillen det hele på hovedet. De gør det med et glimt af underfundighed, ironi og flertydighed. Denne moderne dans rummer et usædvanligt nuanceret bevægelsessprog, en bevidst nuancering af alle bevægelsens elementer som er uhyre avanceret og præcist udtrykt. Der er en utrolig spændvidde af hårdhed og blødhed, af hurtighed og rytmisk raffineret timing, hvor man veksler mellem at være på beat'et og netop at være på off-beat'et, sådan som det kendes fra eksperimenterende avantgarde jazz musik. Denne rytmiske frasering er meget bevidst og med til at gøre, at bevægelsen 'svinger'. Der er en præcision i linjer og bevægelser, som rummer en usædvanlig afslappethed og en total kontrol og dermed en selvfølgelighed og nuancering i udtrykket, som er usædvanlig.

De tilpasser sig med en forbløffende fleksibilitet det gulv eller den scene, der er til rådighed, og formår alligevel med deres energi og kropsbevægelse at få rummet til at udvide sig og pulsere $\mathrm{i}$ intense rytmer. En særegen koncentreret og meget bevidst leg med hver enkelt lille kropsdel. Linjerne i kroppen er skæve, asymmetriske. De spiller på overraskende kontraster. Energien er 


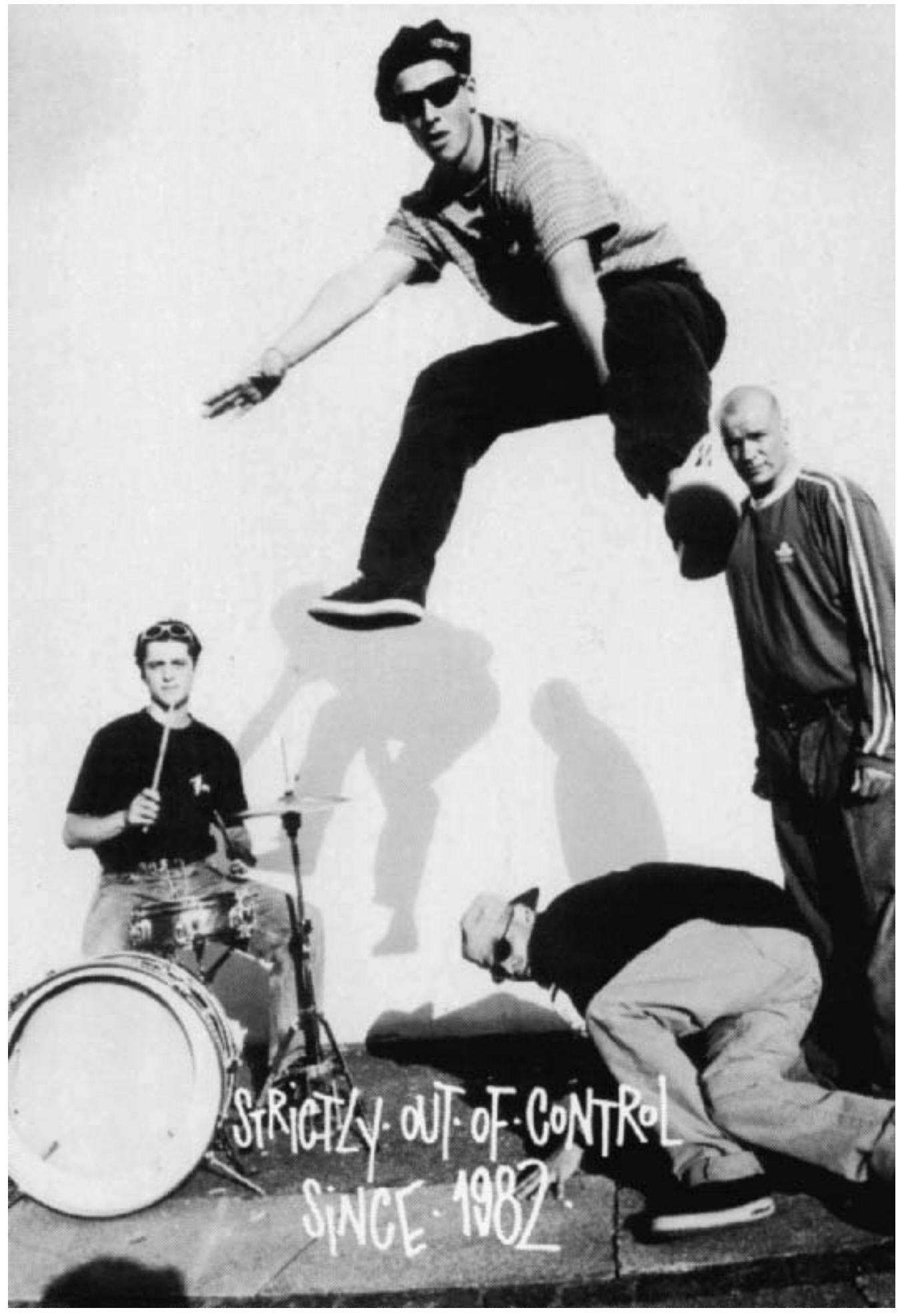


hele tiden $h ø j$. Det mere fanden-i-voldske og imponerende indgår vekslende med subtile trin og gestus i en præcis trinkoreografi.

Den bevidst tilbagelænede stil afspejler sig også i deres livsstil iøvrigt f.eks i deres måde at lave aftaler på. De er altid helt afslappede, måske husker de aftalen, måske har de glemt den. Der er ingen panik at spore, selv om de ikke helt kender tid og sted et par timer før, de skal optræde. De er fuldstændig afslappede, optaget af at snakke, komme med små indforståede bemærkninger, drikke cola og spise løs af oste-og pølsemadder.

Stilen i deres dans er meget 'mimisk', men meget mere abstrakt end klassisk mime plejer at være. Der er som regel ikke nogen konkret sammenhængende historie, der fortælles. Bevægelserne er abstrakte. De kropslige billeder kan være glimt af genkendelige billeder, men i sammenhænge, som gør dem flertydege, overraskende og uforudsigelige. Der ikke er en naturalistisk begyndelse og slutning, men kropsbilleder i bevægelse, der fanger opmærksomheden. Jeg oplever det som et abstrakt legemliggjort digt over det moderne menneskes univers.

Der er et klart samspil i gruppen lige fra trommeslageren til den enkelte danser til danserne indbyrdes. Der er bidder med nøje fastlagt fælleskoreografi og der er stykker, hvor hver enkelt danser sin dans, mens de andre blot er tilskuere. Der er også karakteristiske forskelle på de enkelte danseres udtryk og stil.

Umiddelbart er det en dansestil, som udtrykker en maskulin energi, forstået som en skarp, hård, direkte kropsrytme. Kropsartikulationen er meget accentueret. Det er en sofistikeret isolationsteknik. Denne kropsartikulation er til gengæld så nuanceret, så fleksibel, så lidt 'stiv', at den også rummer et brud på traditionelle normer for mænds kropsudtryk. Normer, hvor den stærke mand i sin karikatur netop afbildes med en helt firkantet fastlåst, kontrolleret krop uden nogle bølger eller brud på de lige linjer. Her rummer hiphopdansen en klar udvidelse af et klassisk maskulint kropssprog.

Dynamikken veksler mellem slow motion og meget hurtig, men der er ingen diskussion om, at det hurtige, markerede rytmiske er den dominerende bevægelseskvalitet. Der er slow motion indslag, men de er kortvarige og relativt sjældne kvaliteter i bevægelsen.

Der er ikke rigtig nogle langsomme glidende eller kærtegnende bevægelser. Der er heller ingen sving, hvor hele kroppen indgår, men nok svingimpulser fra dele af kroppen brugt mere aggressivt, skarpt og markeret. Den fysiske brug af rummets volumen er relativt lille, men den psykiske energiudladning er altid stor.

\section{Tre billedassociationer}

Der er tre billedassociationer, der falder mig ind, når jeg ser Out of Control danse nemlig:

1) Klovnen 2) Barnet og 3) Robotten. Disse billeder udspringer først og fremmest af bevægelsesstilen, men understreges også af den bevidst valgte tøjstil, der er nonchalent og lidt en mellemting mellem 'klovnekostume', 'legedragt' og 'fængselskostume'.

\section{Klovnen og barnet}

Klovnen dækker også artisten, gøgleren, outsideren og oprøreren. Den, der tør overraske sig selv og gøre det uforudsigelige, det groteske. Den, der helt konkret vender tingene på hovedet. Barnet føler jeg kommer til udtryk i kraft af spontaneiteten, det 
ægte og det legende, næsten skitseagtige i kroppens bevægelser. Kroppen er hele tiden i bevægelse. Der er ikke så meget fokus på stillingen, som position, kun som punkter man flyder igennem. Det er let at få disse associationer i kraft af især breakdancedelen med de mange stuntagtige og akrobatiske indslag, hvor der vendes op og ned på kroppen og balanceres og snurres på ryg, skuldre, hoved og hænder, men også udtryk fra electric boogie stilen understreger disse billeder f.eks i form af det meget fantasifulde 'splatteragtige' kropssprog, som kommer til udtryk i de overraskende isolationsteknikker og i de forskellige kropbølger, som bl.a kan give benene et 'gummiagtigt'og dermed klovneagtigt udtryk. Der er hovedspring og andre elementer kendt fra redskabsgymnastikkens gulvøvelser, fra cirkusartisten og fra capuera, men $i$ en mere fræk og fanden-ivolds form uden traditionelle æstetiske krav om lige linjer og symmetriske bevægelser. Tværtimod er det æstetiske krav, at formen ikke må være overstrakt, symmetrisk og forudsigelig. Formen leger med det spontane i udtrykket, igen som barnet og klovnen, der tumler rundt og overraskes og jubler over egne indfald og ikke bekymrer sig om lange, strakte linjer, men i stedet lægger al vægten på selve det at gøre bevægelsen og leve den. En følelse og et indtryk af, at kroppen har uendelig mange led, at den kan være 'fri', at den kan være kraftbetonet, men samtidig ironisk, sensitiv og overraskende.

\section{Robotten}

Robotten kommer især til udtryk i det mekaniske, det rykagtige og meget spændte, særligt tydeligt i 'locking'stilen med de meget skarpe fastlåsninger, som kobles på electricboogiens isolationsteknik. Det robotagtige understreges også af, at forflyt- ninger altid er i lige retninger. Lige til siden. Lige frem. Drejningerne er ultraskarpe. Kropsdelene bruges adskilt og akcentueret. Der er noget robotagtigt både over brugen af rummet og af kroppen. Noget meget fastlagt med understregning af de rene retninger og skarpe linjer $\mathrm{i}$ en stor kontrast til den anden side af idealet om at være spontan, fri og personlig i udtrykket. Men det robotagtige brydes også hele tiden. Det er ikke nogen standard robot. Det er en løssluppen, fanden-i-voldsk robot, en oprører, en bajads, inderst inde et uskyldigt barn, som leger. Bevægelsesudtrykket rummer en spændvidde af kontraster, som ikke lader sig beskrive i et billede. Det er en robot, der lynhurtigt gennembryder sine egne stiliseringer med en beruset glæde over sine tricks og sin kropslige uforudsigelighed.

\section{Rummer hiphopkulturen spirer til en ny bevagelseskultur?}

Hvilke idealer, hvilke værdier er der i hiphopdansen? Hvilken livsstil ligger der i hiphopkulturen? Hvilke følelser og længsler kommer til udtryk? Er hiphoppen en reaktion på en stresset, fastlåst livsstil. Et friområde med idealer om barnets verden af ubundethed, idealer om at kunne flyde med øjeblikket og give det spontant udtryk, at kunne gå ind i kroppens måde at stimulere energien på, at hoppe, dreje, snurre, gentage indtil rytmen får alt til at hoppe, dreje snurre? Er hiphopdansen en bevægelsesteknik, der giver en momentan oplevelse af $\emptyset$ get energi, af frihed, af intens følelse af at være levende? Og kan denne bevidsthed om det spontane og frie forplante sig fra hiphopdansen ud i en bredere kulturel sammenhæng? Rummer hiphopdansen et for- 
søg på at udtrykke længslen efter en forvandling, der rummer en polaritet af byens kultur, byens rytmer og frisættelsen, generobringen af en fri, sanselig og uhyre udtryksfuld krop i og med, at de behersker næsten hver eneste fiber i kroppen fra det hårdeste til det blødeste, fra det mest spændte robotagtige til det mest flydende gummiagtige? Fra den mest raffinerede leg med en mekanisering af kroppen, som overskrider sit eget signal om det mekaniske, robotagtige ved samtidig at rumme overraskelsen, det organiske flow, den totalt levende, bølgende ryg, der gennembryder de spændte, skarpe linjer. Er hiphoppen et af de steder, hvor drømmen om den levende, frigjorte krop er i live og udvikler sig? Og hvis det er tilfældet, kan denne side af hiphoppen så overvinde pressens modbilleder af hiphoppen som vold, stoffer og forbrydelse?

For mig at se rummer hiphopkulturen sådan, som jeg har mødt den og beskrevet den her en masse værdier, som peger i retning af en ny tid, først og fremmest på grund af kulturens kontakt med kreativitetens kilder, som de kommer til udtryk i udforskningen af kroppens sprog, men også fordi hiphopkulturen vokser i et 'frirum', en slags mellemrum uden for det etablerede samfunds regler og normer. Hiphop er en undergrundskultur, som udspringer af gadens rum, et rum med fri tid - uden for arbejde og skole. Et rum uden på forhånd fastlagte æstetiske regler eller andre regler. Drivkraften udspringer fra en ungdomsenergi - en slags forlænget barndom med plads til eksperimenter. De forskellige udtryksformer vokser frem af byens rytmer, et eksperimenterende miljø, med afsæt $\mathrm{i}$ det afrikanske rytmiske udtryk, både verbalt, kropsligt og musikalsk. Det er en undergrundskultur løsrevet fra den brede kulturs regler og normer, og derfor med et enormt kreativt potentiale, som har bredt sig til ungdommen over hele verden, dels via TV og film og måske især via musikvideoer. Det er en kultur, der er vokset ud af børnenes og de unges egne måder at give deres erfaringer udtryk på - og dette udtryk udspringer af en intens kropslig nærvær.

Her er tale om et mode med kreativitet som livsform, med idealer om at udtrykke sig på sin egen måde gennem bevagelse, dans, rytme, poesi og billeder. En ungdomskultur, hvor nøgleordene er : narvar, hurtig puls, pracision og nuancering, men også tidløshed, flydende energi, leg og overskridelse af stive granser og normer, såvel fysiske som holdningsmassige. Et mode med en stolthed over en kultur, hvis essens er kreativiteten, legen og humoren. En kultur, hvor det handler om at udtrykke sig autentisk - og hvis filosofiske forbilleder med et skavt smil siges forst og fremmest at vare Steen \& Stoffer. (1996 Watterson) Det unikke ved hiphopkulturen er efter min opfattelse, at der her er tale om en kultur, hvor spontaneitet og kontrol ikke er modsætninger men partnere. Det er helt klart en sjældenhed i den moderne verden og også i idrættens og dansens verden. Det skaber grobund for en utrolig frihed og kreativ kraft, som udvider det personlige og kulturelle udtryk. Her overskrides både normale stilistiske og holdningsmæssige grænser ligesom hiphopkulturen overskrider nationale og racemæssige forskelle. Det kan give håb om, at denne enorme kreative kraft, den positive side af hiphopkulturen, kan vokse sig stærk og på sin egen måde inspirere andre dele af det moderne liv og ikke mindst inspirere bevægelseskulturen, både inden for idræt og dans, hvad der også er masser af tegn på. Hvad betydning det så kan få for selve hiphopkulturen som undergrundskultur er en 
anden historie. Selve undergrunden i kulturen er meget opmærksomme på den udfordring, som ligger i at komme i mediernes søgelys. Hvad sker der, når det der var skjult i undergrunden bliver udstillet, efterlignet og udbudt til salg?

\section{Noter}

Elias, Norbert, The Symbol Theory, Sage Publications.1989.

Elias, Norbert and Eric Donning Quest for Excitement. Sport and leisure in the Civilising process. P.50 Basil Blackwell Inc. 1986

Elias, Norbert Was ist Soziologie? Juventa Verlag. 1971.

Engel, Lis. Psykofysisk træning: Helhedserfaring og bevidsthedsændring. Ph.d. DHL's forlag. 1991.

Förnäs, Johan, Ulf Boëthius, Sabina Cwejman, Hillevi Ganetz \& Bo Reimer: Gender and identity in transformation. Fus- rapport nr 3 1991. Young styles and forms of expression Fus rapport $\mathrm{nr} 4$, 1992.

Hansen, Jørn og Søren Nagbøl Ollerup Gymnastikhøjskole - Livsrum - bevægelseskultur og social identitet. pp. 21-45. Livsrum, Myter og praktikker. Idrætshistorisk årbog 1992.

Lorenzer, Alfred Kulturanalysen. Psychoanalytischen Studien zur Kultur . Fischer Verlag. 1986.

Lorenzer, Alfred Das Konzil der Buchhalter. Die Zerstörung der Sinnlichkeit. Europäische Verlagsanstalt. 1981.

Nagbøl, Søren, Socialisationspolitiske Aspekter i Norbert Elias 'Sociologi . Magisterkon ferensspeciale. Institut for Idéhistorie. Århus Universitet. 1980.
Nagbøl, Søren, Matrix, 12. Årgang, nr 1 august 1995 p 7-37 Konstrueret Virkelighed. En oplevelsesanalyse der berører arkitekturen, litteraturen, billedkunsten, medierne, virkelighe den og os. 1995.

Nagbøl, Søren, Berøvende Arkitektur. En Oplevelsesanalyse af Arkitekturmuseet i Frankfurt am Main. Arkitektens Forlag. 1994.

Nagbøl, Søren, Bewegungsräume. Körperanthropologische Beiträge. »Ollerup College of Physical Education - Living Space - Culture of Movement and Social Identity.« 1996.

Nagbøl, Søren At bade regionalt, nationalt og overnationalt. Helgoland på Amager. kropskultur og idræt. Idrætshistorisk årbog 1990. 6. årgang pp 2432.

Nelson, George. Buppies, B-boys, Baps \& Bohos. Harper Perennial 1992.

Schulze, Gerhard, Die Erlebnisgesellschaft: Frankfurt am Main \& New York: Campus. 1992.

Ziehe, Thomas Zeitvergleiche. Jugend in kulturellen modernisierungen Weinheim \& München: Juventa. 1991.

Watterson, Bill. The Calvin and Hobbes Tenth Anniversary Book.Warner Books. 1996. 